\title{
Antifungal and antioxidant activity of fatty acid methyl esters from vegetable oils
}

\author{
MARIA E.A. PINTO ${ }^{1}$, STHÉFANE G. ARAÚJO ${ }^{1}$, MARCELA I. MORAIS ${ }^{1}$, NíVEA P. SÁ ${ }^{2}$, CAROLINE M. \\ LIMA $^{2}$, CARLOS A. ROSA ${ }^{2}$, EZEQUIAS P. SIQUEIRA ${ }^{3}$, SUSANA JOHANN ${ }^{2}$ and LUCIANA A.R.S. LIMA ${ }^{1}$ \\ ${ }^{1}$ Campus Centro-Oeste Dona Lindu, Universidade Federal de São João Del Rei, Rua Sebastião \\ Gonçalves Coelho, 400, Chanadour, 35501-296 Divinópolis, MG, Brazil \\ ${ }^{2}$ Departamento de Microbiologia, Instituto de Ciências Biológicas, Universidade Federal de Minas \\ Gerais, Avenida Antônio Carlos, 6627, Pampulha, 31270-901 Belo Horizonte, MG, Brazil \\ ${ }^{3}$ Centro de Pesquisas René Rachou/Fiocruz, Avenida Augusto Lima, 1715, Barro Preto, 30190-002 Belo Horizonte, MG, Brazil
}

Manuscript received on December 23, 2016; accepted for publication on March 3, 2017

\begin{abstract}
Fatty acid methyl esters (FAMEs) were obtained from vegetable oils of soybean, corn and sunflower. The current study was focused on evaluating the antifungal activity of FAMEs mainly against Paracoccidioides spp., as well as testing the interaction of these compounds with commercial antifungal drugs and also their antioxidant potential. FAMEs presented small $\mathrm{IC}_{50}$ values $(1.86-9.42 \mu \mathrm{g} / \mathrm{mL})$. All three FAMEs tested showed antifungal activity against isolates of Paracoccidioides spp. with MIC values ranging from 15.6$500 \mu \mathrm{g} / \mathrm{mL}$. Sunflower FAMEs exhibited antifungal activity that extended also to other genera, with an MIC of $15.6 \mu \mathrm{g} / \mathrm{mL}$ against Candida glabrata and C. krusei and $31.2 \mu \mathrm{g} / \mathrm{mL}$ against C. parapsilosis. FAMEs exhibited a synergetic effect with itraconazole. The antifungal activity of the FAMEs against isolates of Paracoccidioides spp. is likely due to the presence of methyl linoleate, the major compound present in all three FAMEs. The results obtained indicate the potential of FAMEs as sources for antifungal and antioxidant activity.
\end{abstract}

Key words: antifungal, antioxidant, fatty acid methyl esters, vegetable oils.

\section{INTRODUCTION}

Antioxidant compounds are capable of inhibiting or delaying lipid oxidation, which is associated with the appearance of degenerative or chronic diseases. Thus, antioxidants act to prevent or avoid incidence of cancer, diabetes, atherosclerosis, coronary heart disease and the aging process (Rufino et al. 2011). Natural substances with known antioxidant potential are phenolic compounds (flavonoids and

Correspondence to: Luciana A. R. S. Lima

E-mail: luarsantos@ufsj.edu.br phenolic acids), vitamins A, C, E and carotenoids which, in different proportions and quantities, can be obtained from foods of plant origin, such as vegetables, fruits, teas, herbs, beans and oil seeds (Ara and Nur 2009, Arnao et al. 2001). Several studies have suggested that the development of chronic or degenerative diseases can be decreased with the regular consumption of vegetables or fruits (Chu et al. 2002). Therefore, in recent years, the search for natural antioxidants, especially of plant origin, has greatly increased (Lima et al. 2010). 
Paracoccidioidomycosis (PCM) is a systemic mycosis caused by fungi of the genus Paracoccidioides, and two species are known, $P$. brasiliensis and P. lutzii. PCM is a disease limited to Latin America and is a common cause of deaths from fungal diseases. PCM is the eighth most important cause of mortality from chronic infectious diseases reaching rates of 1.65 deaths per $10^{6}$ habitants (Bocca et al. 2013, Coutinho et al. 2002, Prado et al. 2009). There are some drugs available to treat PCM; itraconazole therapy is the first choice to control the mild to moderate clinical forms but this therapy is not easily available in most of the endemic regions. Consequently, sulfamethoxazoletrimethoprim (SMX-THT) is a useful option; this drug is freely distributed by the Brazilian Ministry of Health. The main disadvantage of SMX-THT is the need for long-term treatment (more than 12 months) in moderate and severe cases which can lead patients to abandon treatment (Brummer et al. 1993, Paniago et al. 2003, Travassos et al. 2008). Amphotericin B therapy is the best choice for severe cases of PCM, but toxicity, mainly nephrotoxicity, is related to this drug which will sometimes require discontinuation of this therapy (de Oliveira et al. 2015, Ferreira 2009, ShikanaiYasuda 2015). Relapses, a common event in PCM patients, associated with toxicity represent an unresolved problem in the conventional therapeutic approach (Travassos et al. 2008, Travassos and Taborda 2012). Due to these facts it is necessary to research new drugs that are safer, more effective and cheaper and with shorter periods of therapy for the treatment of PCM.

Fatty acids are the most abundant component of oils, the most commonly found being stearic, palmitic, oleic, linoleic and linolenic acids (Cabral 2005). The antibacterial and antifungal properties of vegetable oils are reported in the literature, these being especially attributed to the presence of fatty acids (Desbois and Smith 2010, Erdemoglu and Kusmenoglu 2003). However, some works done with methyl esters showed their potential as antifungals (Abdelillah et al. 2013, Agoramoorthy et al. 2007, Chandrasekaran et al. 2011, Golebiowiski et al. 2013, Lima et al. 2011), but these works are still scarce, so it is important to test these compounds. Fatty acid methyl esters (FAMEs) are obtained from vegetable oils. This work is focused on evaluating the antifungal activity of FAMEs from vegetable oils against Paracoccidioides spp., and also antioxidant potential by the scavenging effect on 2,2-diphenyl-1-picrylhydrazyl (DPPH) radicals.

\section{MATERIALS AND METHODS}

\section{CHEMICALS}

Soybean, corn and sunflower vegetable oils were obtained from ABC Industry, Trade SA and Caramuru Foods SA (Brazil), respectively. All PA and HPLC grade reagents used were purchased from Vetec (Brazil) and Sigma (St. Louis, USA), respectively. Amphotericin B, 2,6-bis(1,1dimethylethyl)-4-methylphenol (BHT), DPPH, 2',7'-dichlorofluorescein diacetate, ascorbic acid (AA), methyl palmitate, methyl stearate, methyl oleate, methyl linoleate, methyl linolenate, palmitic acid, stearic acid, oleic acid, linoleic acid, linolenic acid, synthetic medium RPMI and morpholine propanesulfonic acid (MOPS) from Sigma-Aldrich (St. Louis, MO, USA). Dihidrorhodamine 123 was obtained from Invitrogen (USA). Sabouraud dextrose agar was purchased from Oxoid (Basingstoke, UK), SMX-THT from Roche (Rio de Janeiro, Brazil) and fluconazole from Pfizer Pharmaceutical (USA).

\section{PREPARATION OF METHYL ESTERS}

Vegetable oils $(1 \mathrm{~g})$ were refluxed with $1.0 \mathrm{~mol} / \mathrm{L}$ methanolic sodium hydroxide solution for $30 \mathrm{~min}$ and then extracted with ethyl ether. The aqueous phase was acidified with $1.0 \mathrm{~mol} / \mathrm{L}$ hydrochloric acid solution and extracted with ethyl ether. The 
organic phase was dissolved in hexane and then refluxed with $2 \% \mathrm{v} / \mathrm{v}$ sulfuric acid methanolic solution for $60 \mathrm{~min}$. After extraction and solvent elimination FAMEs were obtained (Lima et al. 2011).

ANALYSIS OF METHYL ESTERS BY GAS CHROMATOGRAPHY-MASS SPECTROMETRY (GCMS)

Analysis of FAMEs by GC-MS was performed on Shimadzu CG-MS QP5050A apparatus, using impact electron at $1.2 \mathrm{kV}$, helium as the carrier gas and a Supelco PTE-5 column $(30 \mathrm{~m} \times 0.25 \mathrm{~mm}$, df $0.25 \mu \mathrm{m}$ ). The temperature was maintained at $120^{\circ} \mathrm{C}$ and programmed to $300^{\circ} \mathrm{C}$ with increments of $5{ }^{\circ} \mathrm{C} / \mathrm{min}$; injection and detector temperatures were $230{ }^{\circ} \mathrm{C}$. The split ratio was $1 / 10$. The mass range was $40-500 \mathrm{~m} / z$ and flow rate was $2 \mathrm{~mL} /$ min. FAMEs were identified by using the NIST 2.0 Library database search and by comparison of their retention times with those of standards.

DPPH RADICAL-SCAVENGING ASSAY

The radical-scavenging ability of FAMEs was analyzed compared to standards BHT and AA based on reaction with DPPH radicals. The DPPH method was adapted for use with microplates (Araújo et al. 2013). A solution of DPPH (0.002\% $\mathrm{w} / \mathrm{v}$ ) was prepared in $80 \%$ methanol. Exactly 75 $\mu \mathrm{L}$ of sample or standard $(1,10,100,250$ and $500 \mu \mathrm{g} / \mathrm{mL}$ ) was added to $150 \mu \mathrm{L}$ of DPPH, and the microplate was then covered and left in the dark (once) at room temperature $\left(25{ }^{\circ} \mathrm{C}\right) ; 80 \%$ methanol was used for baseline correction. The absorbance was measured in a spectrophotometer (BioTek Power Wave XS2/US) at $517 \mathrm{~nm}$, after $30 \mathrm{~min}$. Scavenging ability was calculated by the following equation (Burda and Oleszek 2001): , where $\mathrm{Abs}_{\text {control }}=$ absorbance of DPPH radicals and $\mathrm{Abs}_{\text {sample }}=$ absorbance of samples or standards + DPPH. The antioxidant activity was expressed as $\mathrm{IC}_{50}$ (concentration of samples necessary to inhibit by $50 \%$ the formation of DPPH radicals, in $\mu \mathrm{g} / \mathrm{mL}$ ). Probit analysis (Finney 1980) was used to calculate the $\mathrm{IC}_{50}$ values. All assays were performed in triplicate.

\section{CULTURE AND MAINTENANCE OF THE FUNGAL ISOLATES}

In this study we used eight isolates of Paracoccidioides brasiliensis representing the three phylogenetic species (PS1, PS2 and PS3) and three isolates of $P$. lutzii, members of the collection of the Microorganism-Host Interaction Laboratory, Biological Science Institute of Universidade Federal de Minas Gerais (UFMG). Paracoccidioides spp. were maintained in YPD (yeast, peptone and dextrose) and subcultures were performed after 7 days of growth at $37{ }^{\circ} \mathrm{C}$. Candida albicans ATCC 18804, C. glabrata ATCC 2001, C. krusei ATCC 200298, C. parapsilosis ATCC 22019, C. tropicalis ATCC 22019, Cryptococcus gattii ATCC 24065 and C. neoformans ATCC 24067 were used in the biological assays. The species of Candida and Cryptococcus were stored frozen at $-80{ }^{\circ} \mathrm{C}$.

The inoculum of Paracoccidioides was done according Hahn and Hamdan (2000). The resulting suspensions were diluted in RPMI $1640(1: 10)$ to obtain the final inoculum with $1-5 \times 10^{5}$ yeasts/ $\mathrm{mL}$ (Cruz et al. 2013). For Candida spp. and Cryptococcus spp., the inoculum was obtained with a final concentration of $0.5-2.5 \times 10^{3}$ cells $/ \mathrm{mL}$ for susceptibility testing (CLSI 2008).

\section{ANTIFUNGAL ACTIVITY}

The antifungal activity was evaluated by the minimal inhibitory concentration (MIC) in accordance with the guidelines from the CLSI M27-A3 document (CLSI 2008). The MIC for Paracoccidioides was performed according to the method described by Johann et al. (2010). FAMEs were tested in the range of 2000-7.81 $\mu \mathrm{g} / \mathrm{mL}$, amphotericin B was tested in the range of $1-0.008 \mu \mathrm{g} / \mathrm{mL}$ and SMXTHT $\left(4.49 \times 10^{-3}\right.$ to $\left.2.3 \mu \mathrm{mol} / \mathrm{mL}\right)$ was tested in 
the range of $600-4.6 \mu \mathrm{g} / \mathrm{mL}$. The MIC values correspond to the lowest concentrations that did not allow for the detection of any visual fungal growth. All assays were performed in triplicate and repeated at least once.

\section{ASSESSMENT OF DRUG INTERACTIONS}

The assessment of drug interactions of FAMEs and positive controls (amphotericin B, SMX-THT and itraconazole) were performed according to the described methods (Pyun and Shin 2006, White et al. 1996), using eight serial dilutions of each compound. These dilutions were added to 96-well plates in several combinations of concentrations of the two compounds tested. After that, a suspension of $\mathrm{Pb}-18$, done according to the MIC test, was added to all wells of the plate and cultured for 14 days. The fractional inhibitory concentration (FIC) was obtained by dividing the MIC of the positive control in the presence of FAMEs by the MIC of the positive control alone. The FIC of FAMEs was calculated in the same way. The FIC index (FICI) was obtained by adding both FICs. Synergistic activity was observed when the FICI was $\leq 0.5$, an indifferent effect in the range $0.5<$ FICI $<2.0$ and an antagonistic effect when the FICI was $>2.0$.

\section{CELLULAR REACTIVE OXYGEN SPECIES (ROS)}

The $P$. brasiliensis $\mathrm{Pb}-18$ was cultured in YPD agar during days at $37{ }^{\circ} \mathrm{C}$. Microplate wells received $100 \mu \mathrm{L}$ inoculum containing $1 \times 10^{5} \mathrm{cfu} / \mathrm{mL}$ in RPMI medium without phenol red, and then the probes were added. Briefly, the probe for reactive oxygen species (ROS) (2',7'-dichlorofluorescein diacetate) and reactive nitrogen species (RNS) (dihidrorhodamine 123) were prepared in methanol and PBS, respectively, at $100 \mu \mathrm{M}$ and $20 \mu \mathrm{L}$ were distributed to each well for a final concentration of $10 \mu \mathrm{M}$. Hydrogen peroxide (4M) was included as a control. The drug treatment solutions were evaluated at the respective MIC, in a final volume of $200 \mu \mathrm{L}$. The plates were incubated at $37^{\circ} \mathrm{C}$ in the dark. After 120 hour, the fluorescence was measured with a fluorometer (Biotek Synergy 2 SL Luminescence Microplate Reader/US) using excitation at $485 \mathrm{~nm}$ and emission wavelengths of $530 \mathrm{~nm}$.

\section{STATISTICAL ANALYSIS}

Student's t test was utilized to evaluate the statistical difference between the control group and the group exposed to FAMEs. To evaluate the statistical difference between the three FAMEs tested we used the Newman-Keuls test and ANOVA ( 1 way) to cellular ROS. A $P$ value $<0.05$ was considered statistically significant. The analyses were performed using Prisma 5.0 software.

\section{RESULTS AND DISCUSSION}

\section{ANTIOXIDANT ACTIVITY}

In this study, FAMEs obtained from vegetable oils were investigated by GC-MS. The analysis by GC-MS revealed a high percentage of unsaturated methyl esters (83.95-88.33\%) as compared to saturated methyl esters (11.67-16.05\%). In samples, methyl oleate and methyl linoleate were detected as the major unsaturated methyl esters. Methyl palmitate was the most abundant among the saturated methyl esters, followed by methyl stearate (Table I).

The scavenging effect on DPPH radicals of FAMEs from vegetable oils is presented in Figure 1. FAMEs, BHT and AA revealed an inhibitory effect in a concentration-dependent manner. FAMEs were more effective in scavenging DPPH radicals than $\mathrm{AA}$ at a concentration of $1 \mu \mathrm{g} / \mathrm{mL}$ and BHT at concentrations of 1 and $10 \mu \mathrm{g} / \mathrm{mL}$. FAMEs showed $\mathrm{IC}_{50}$ values of $1.86,9.42$ and $3.33 \mu \mathrm{g} / \mathrm{mL}$ for soybean, corn and sunflower oils, respectively, lower than BHT $(16.36 \mu \mathrm{g} / \mathrm{mL} ; P<0.05)$, but higher than AA $(1.62 \mu \mathrm{g} / \mathrm{mL} ; P<0.05)$. FAMEs obtained from Annona cornifolia seeds also presented 
TABLE I

Composition and percentages of fatty acid methyl esters (FAMEs).

\begin{tabular}{cccccc}
\hline Peak No. & Fatty acids methyl esters & Soybean & Corn & Sunflower & $\begin{array}{c}\text { Annona } \\
\text { cornifolia }\end{array}$ \\
\hline 1 & Methyl palmitate & 12.71 & 12.92 & 6.99 & 16.9 \\
2 & Methyl stearate & 3.34 & 2.03 & 4.68 & 5.6 \\
3 & Methyl oleate & 28.28 & 36.67 & 22.40 & 51.5 \\
4 & Methyl linoleate & 55.67 & 48.38 & 65.93 & 19.1 \\
5 & Methyl myristate & - & - & - & 0.2 \\
6 & Methyl linolenate & - & - & - & 0.8 \\
Total & & 100.00 & 100.00 & 100.00 & 94.1 \\
\hline
\end{tabular}

${ }^{1}$ Lima et al. 2011.

antioxidant activity, with $\mathrm{IC}_{50}=3.83 \mu \mathrm{g} / \mathrm{mL}$ (Lima et al. 2012). Soybean and sunflower FAMEs were more active than the FAMEs of Annona cornifolia.

\section{ANTIFUNGAL ACTIVITY}

The antifungal activity of FAMEs obtained from vegetable oils was evaluated against 18 fungal strains of clinical interest (Table II). Results showed that all FAMEs tested showed antifungal activity against the isolates of Paracoccidioides tested, with values between 15.6 and $500 \mu \mathrm{g} / \mathrm{mL}$. Paracoccidioides brasiliensis Penguin showed more susceptibility to soybean and sunflower FAMEs with an MIC value of $15.6 \mu \mathrm{g} / \mathrm{mL}$, but this isolate was less susceptible to corn FAMEs (MIC $=500 \mu \mathrm{g} / \mathrm{mL}$ ). For $P$. lutzii, isolate 1578 was most susceptible to the FAMEs tested in the present study. Moreover, FAMEs (soybean, corn and sunflower) showed better activity than SMX-THT $(P=0.0001)$ against the isolates of $P$. brasiliensis $\mathrm{Pb}-18, \mathrm{~Pb}-608, \mathrm{~Pb}-1017, \mathrm{~Pb}-9673$ and P. lutzii 01. SMX-THT is used in the treatment of PCM, mainly in endemic regions where other therapy (such as itraconazole) is not easily available; consequently, therapy consisting of SMX-THT is a useful option (de Oliveira et al.2015, Shikanai-Yasuda 2015). The difference in antifungal activity between different FAMEs, against 11 isolates of Paracoccidioides spp., is not statistically significant $(P<0.05)$. MIC values found for SMX-THT and amphotericin $\mathrm{B}$ against the isolates of Paracoccidioides were statistically significant when compared with FAMEs $(P=0.0001)$.

It is interesting to note that when we tested the susceptibility of other fungus genera we observed that only sunflower FAMEs showed activity under the conditions tested in the present study (Table II). This antifungal activity (sunflower FAMEs) was more pronounced against C. krusei, C. glabrata and C. parapsilosis with MIC values of 15.6, 15.6 and $31.2 \mu \mathrm{g} / \mathrm{mL}$, respectively.

Few works reporting the biological activity of FAMEs against pathogenic fungi are found in the literature. Twelve clinical strains of the fungus $P$. brasiliensis were susceptible to FAMEs from seeds of $A$. cornifolia, with MICs in the range between 3.4 and $55.5 \mu \mathrm{g} / \mathrm{mL}$ (Lima et al. 2011). The FAME extract of Excoecaria agallocha presented antifungal activity against Candida albicans, C. krusei, C. parapsilosis and Candida tropicalis (Agoramoorthy et al. 2007). 


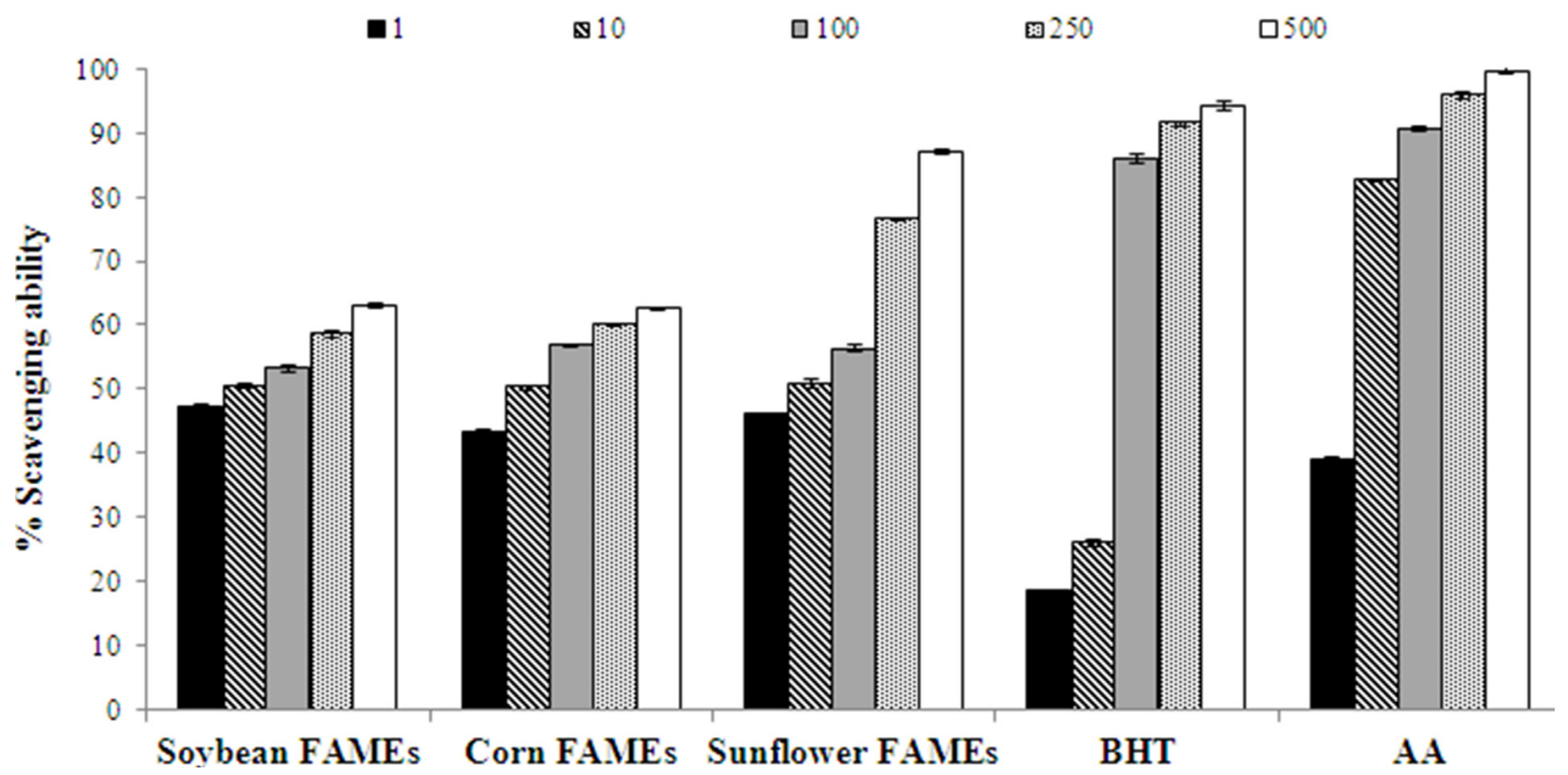

Figure 1 - DPPH radical-scavenging ability of fatty acid methyl esters (FAMEs) at five different concentrations (1, 10, 100, 250 and $500 \mu \mathrm{g} / \mathrm{mL}$ ). Values represent averages \pm standard deviations for triplicate experiments. BHT: 2,6-bis(1,1-dimethylethyl)-4methylphenol; AA: ascorbic acid.

Golebiowiski et al. (2013) reported the antifungal activity of FAMEs from Calliphora vomitoria against entomopathogenic fungi, protecting this ectoparasite against entomopathogenic microorganisms present in its habitat. Furthermore, these authors showed that when individual FAMEs were tested they presented weak antifungal activity, but the mixture of FAMEs found in living forms of C. vomitoria was more active. These experiments are in agreement with those of the present study where the mixture of FAMEs presented antifungal activity.

In the present work we also tested the antifungal activity of standards of the methyl esters which were present in the FAMEs (Table III). Of these methyl esters tested only methyl linoleate showed antifungal activity against $P$. brasiliensis (Pb-18), with an MIC value of $62.5 \mu \mathrm{g} / \mathrm{mL}$ (Table III). It is interesting to note that sunflower FAMEs had a higher percentage of methyl linoleate (65.93\%) and also presented better antifungal activity, with $54.54 \%$ of isolates of Paracoccidioides tested with an $\mathrm{MIC}$ value $\leq 62.5 \mu \mathrm{g} / \mathrm{mL}$. The other two FAMEs tested also followed this pattern; soybean FAMEs containing 55.67\% methyl linoleate showed antifungal activity with an MIC value $\leq 62.5 \mu \mathrm{g} / \mathrm{mL}$ for $36.36 \%$ of isolates of Paracoccidioides tested and corn FAMEs (48.38\% methyl linoleate) with $27.27 \%$ of isolates tested with an MIC value $\leq 62.5$ $\mu \mathrm{g} / \mathrm{mL}$. Probably, methyl linoleate is responsible for the antifungal activity of the FAMEs studied, because it is also present in a greater concentration in all the FAMEs tested (Table I). In present work we also observed the production of reactive oxygen (ROS) by methyl linoleate, sunflower and corn FAMEs (Figure 2) with production significantly compared to the control group (P. brasiliensis 18 without treatment $)(P<0.05)$. Methyl linoleate is able to produce hydroperoxide (Yamamoto et al. 1984) and probably this property is responsible for the antifungal activity of this compound in the present work. Therefore the ROS production could be related with antifungal activity of sunflower and corn FAMEs and methyl linoleate compound 
TABLE II

Minimal inhibitory concentration (MIC) of FAMEs against 18 clinically important fungi.

\begin{tabular}{|c|c|c|c|c|c|}
\hline \multirow[b]{2}{*}{ Fungi } & $\begin{array}{c}\text { Soybean } \\
\text { FAMEs }\end{array}$ & $\begin{array}{c}\text { Corn } \\
\text { FAMEs }\end{array}$ & $\begin{array}{c}\text { Sunflower } \\
\text { FAMEs }\end{array}$ & Amphotericin B & SMX-THT \\
\hline & $\begin{array}{c}\text { MIC } \\
\mu \mathrm{g} / \mathrm{mL}\end{array}$ & $\begin{array}{c}\text { MIC } \\
\mu \mathrm{g} / \mathrm{mL}\end{array}$ & $\begin{array}{c}\text { MIC } \\
\mu \mathrm{g} / \mathrm{mL}\end{array}$ & $\begin{array}{c}\text { MIC } \\
\mu \mathrm{g} / \mathrm{mL}\end{array}$ & $\begin{array}{c}\text { MIC } \\
\mu \mathrm{g} / \mathrm{mL}\end{array}$ \\
\hline Candida albicans & $\geq 2000$ & $\geq 2000$ & 500 & 0.25 & - \\
\hline Candida glabrata & $\geq 2000$ & $\geq 2000$ & 15.6 & 0.125 & - \\
\hline Candida krusei & 250 & $\geq 2000$ & 15.6 & 0.5 & - \\
\hline Candida parapsilosis & $\geq 2000$ & $\geq 2000$ & 31.2 & 0.5 & - \\
\hline Candida tropicalis & $\geq 2000$ & $\geq 2000$ & $\geq 2000$ & 1.0 & - \\
\hline Cryptococcus gattii & $\geq 2000$ & 2000 & 125 & 1.0 & - \\
\hline Cryptococcus neoformans & $\geq 2000$ & $\geq 2000$ & 1000 & 1.0 & - \\
\hline Paracoccidioides brasiliensis $P 18$ & 125 & 125 & 62.5 & 0.25 & 300 \\
\hline Paracoccidioides brasiliensis 470 & 125 & 250 & 125 & 0.125 & 75 \\
\hline Paracoccidioides brasiliensis EPM83 & 125 & 250 & 62.5 & 0.125 & 150 \\
\hline Paracoccidioides brasiliensis 608 & 31.2 & 62.5 & 62.5 & 0.015 & 300 \\
\hline Paracoccidioides brasiliensis AP & 125 & 125 & 125 & 0.125 & 75 \\
\hline Paracoccidioides brasiliensis 1017 & 125 & 125 & 62.5 & 0.062 & 150 \\
\hline Paracoccidioides brasiliensis Pinguim & 15.6 & 500 & 31.2 & 0.125 & 300 \\
\hline Paracoccidioides brasiliensis 9673 & 62.5 & 62.5 & 62.5 & 0.062 & 300 \\
\hline Paracoccidioides lutzii 01 & 125 & 250 & 250 & 0.125 & 300 \\
\hline Paracoccidioides lutzii ED01 & 125 & 250 & 250 & 0.031 & 75 \\
\hline Paracoccidioides lutzii 1578 & 62.5 & 62.5 & 125 & 0.062 & 75 \\
\hline
\end{tabular}

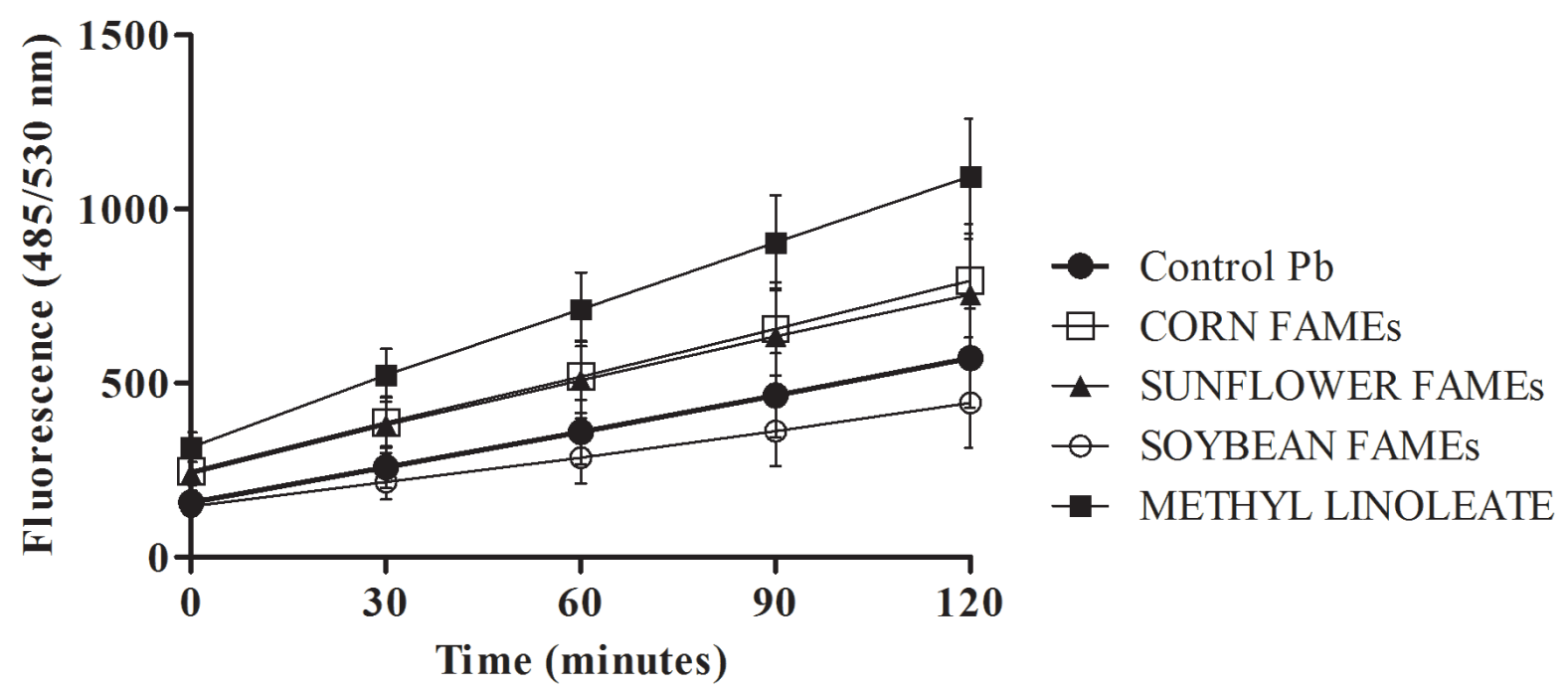

Figure 2 - Production of reactive oxygen species (ROS) in Paracoccidioides brasiliensis after treatment with FAMEs and methyl linoleate. Treatments with Corn and Sunflower FAMEs increased ROS production significantly compared to the control group $(P$ $<0.05)$ One-way analysis of variance (ANOVA) and Kruskal-Wallis multiple-comparison tests. 
TABLE III

Minimal inhibitory concentration (MIC) of standards of fatty acids and methyl esters against important fungi.

\begin{tabular}{|c|c|c|c|c|}
\hline & $\begin{array}{l}\text { C. neoformans } \\
\text { ATCC } 24067\end{array}$ & $\begin{array}{c}C . \text { gatti } \\
\text { ATCC } 24065\end{array}$ & $\begin{array}{c}\text { C. albicans } \\
\text { ATCC } 18804\end{array}$ & $\begin{array}{c}\text { P. brasiliensis } \\
\text { Pb18 }\end{array}$ \\
\hline & $\begin{array}{c}\mathrm{MIC} \\
\mu \mathrm{g} / \mathrm{mL}\end{array}$ & $\begin{array}{c}\mathrm{MIC} \\
\mu \mathrm{g} / \mathrm{mL}\end{array}$ & $\begin{array}{c}\mathrm{MIC} \\
\mu \mathrm{g} / \mathrm{mL}\end{array}$ & $\begin{array}{c}\mathrm{MIC} \\
\mu \mathrm{g} / \mathrm{mL}\end{array}$ \\
\hline Palmitic acid & $\geq 2000$ & $\geq 2000$ & $\geq 2000$ & $\geq 2000$ \\
\hline Stearic acid & $\geq 2000$ & $\geq 2000$ & $\geq 2000$ & $\geq 2000$ \\
\hline Oleic acid & $\geq 2000$ & $\geq 2000$ & $\geq 2000$ & 250 \\
\hline Linoleic acid & $\geq 2000$ & $\geq 2000$ & $\geq 2000$ & 7.8 \\
\hline Methyl palmitate & $\geq 2000$ & $\geq 2000$ & $\geq 2000$ & $\geq 2000$ \\
\hline Methyl stearate & $\geq 2000$ & $\geq 2000$ & $\geq 2000$ & $\geq 2000$ \\
\hline Methyl oleate & $\geq 2000$ & $\geq 2000$ & $\geq 2000$ & $\geq 2000$ \\
\hline Methyl linoleate & $\geq 2000$ & $\geq 2000$ & $\geq 2000$ & 62.5 \\
\hline Amphotericin B & 1.0 & 1.0 & 0.25 & 0.25 \\
\hline SMX-THT & - & - & - & 300 \\
\hline
\end{tabular}

present in these FAMEs could be responsible for ROS production.

Methyl linoleate has already been tested against inhibition of the in vitro proliferation of human tumor cell lines; this compound showed antiproliferative activity with an $\mathrm{IC}_{50}$ of $250 \mu \mathrm{g} /$ $\mathrm{mL}$, but not induction of differentiation. This is an interesting finding, because 5-fluorouracil is also a known antitumor compound that does not induce differentiation and is currently used as an antifungal (Lampronti et al. 2003).

In the present work we also tested the antifungal activity of standards of fatty acids (Table III) because these compounds were present in the oils (sunflower, soybean and corn oils) that originated the FAMEs. Although two of these compounds (oleic acid and linoleic acid) exhibited interesting antifungal activity against $\mathrm{Pb}-18$, the oils did not present activity (data not shown).

To explore the possibility of developing more powerful combination therapies of FAMEs with other antifungal drugs, a checkerboard micro-titer test was carried out. FAMEs showed an antagonistic effect with amphotericin B and an indifferent effect with SMX-THT (Table IV). FAMEs showed a synergetic effect with itraconazole. This illustrates one important result, because it could lead to the development of a new combination therapy using lower concentrations of itraconazole in a shorter treatment time, which would reduce the side effects of patients. Itraconazole interferes in ergosterol synthesis, leading to cell membrane perturbation (Odds et al. 2003). Alteration in membrane permeability could allow increased concentrations of FAMEs to penetrate the cell, resulting in cell death.

\section{CONCLUSIONS}

In the search for new drugs with antifungal and antioxidant properties, FAMEs (obtained from vegetable oils of soybean, corn and sunflower) might be good candidates: these esters presented better radical-scavenging activity and $\mathrm{IC}_{50}$ values than BHT, a commercial antioxidant. All three FAMEs tested showed antifungal activity against isolates of Paracoccidioides spp. with MIC values ranging from $15.6-250 \mu \mathrm{g} / \mathrm{mL}$. Sunflower 
TABLE IV

Fractional inhibitory concentration (FIC) and FIC index (FICI) of FAMEs against Paracoccidioides brasiliensis isolate $\mathrm{Pb}-18$.

\begin{tabular}{|c|c|c|c|c|}
\hline Compounds & $\begin{array}{c}\text { MIC in combination } \\
\mu \mathrm{g} / \mathrm{mL} \\
\end{array}$ & $\begin{array}{c}\text { MIC alone } \\
\mu \mathrm{g} / \mathrm{mL} \\
\end{array}$ & FIC & FICI \\
\hline 1. Soybean FAMEs & 3.9 & 125 & 0.031 & \multirow{2}{*}{4.0312} \\
\hline 2. Amphotericin B & 1.0 & 0.25 & 4 & \\
\hline 1. Soybean FAMEs & 3.9 & 125 & 0.0312 & \multirow{2}{*}{0.5312} \\
\hline 2. SMX-THT & 150 & 300 & 0.5 & \\
\hline 1. Soybean FAMEs & 3.9 & 125 & 0.0312 & \multirow{2}{*}{0.0462} \\
\hline 2. Itraconazole & 0.0009 & 0.06 & 0.0150 & \\
\hline 1. Corn FAMEs & 3.9 & 125 & 0.0312 & \multirow{2}{*}{8.0312} \\
\hline 2. Amphotericin B & 2 & 0.25 & 8 & \\
\hline 1. Corn FAMEs & 3.9 & 125 & 0.0312 & \multirow{2}{*}{0.5312} \\
\hline 2. SMX-THT & 150 & 300 & 0.5 & \\
\hline 1. Corn FAMEs & 3.9 & 125 & 0.0312 & \multirow{2}{*}{0.0612} \\
\hline 2. Itraconazole & 0.0018 & 0.06 & 0.0300 & \\
\hline 1. Sunflower FAMEs & 3.9 & 62.5 & 0.0624 & \multirow{2}{*}{4.0624} \\
\hline 2. Amphotericin B & 1 & 0.25 & 4 & \\
\hline 1. Sunflower FAMEs & 3.9 & 62.5 & 0.0624 & \multirow{2}{*}{0.5624} \\
\hline 2. SMX-THT & 150 & 300 & 0.5 & \\
\hline 1. Sunflower FAMEs & 3.9 & 62.5 & 0.0624 & \multirow{2}{*}{0.0774} \\
\hline 2. Itraconazole & 0.0009 & 0.06 & 0.0150 & \\
\hline
\end{tabular}

FAMEs also exhibited antifungal activity that extended to other genera, with an MIC of 15.6 $\mu \mathrm{g} / \mathrm{mL}$ against Candida glabrata and C. krusei and $31.2 \mu \mathrm{g} / \mathrm{mL}$ against $C$. parapsilosis. FAMEs exhibited a synergetic effect with itraconazole. The antifungal activity of the FAMEs against isolates of Paracoccidioides spp. is likely due to the presence of methyl linoleate, the major compound present in all three FAMEs. This work provided knowledge, for the first time, of the antioxidant and antifungal activity of FAMEs obtained from vegetable oils and indicates the potential of FAMEs as a source of antifungal and antioxidant activity.

\section{ACKNOWLEDGMENTS}

The authors are grateful to the Conselho Nacional de Desenvolvimento Científico e Tecnológico (CNPq), Fundação de Amparo a Pesquisa do Estado de Minas Gerais (FAPEMIG) and Coordenação de
Aperfeiçoamento de Pessoal de Nível Superior (CAPES) for their fellowships. The authors do not have any conflicts of interest.

\section{REFERENCES}

ABDELILLAH A, HOUCINE B, HALIMA D, MERIEM CS, IMANE Z, EDDINE SD, ABDALLAH M AND DAOUDI CS. 2013. Evaluation of antifungal activity of free fatty acids methyl esters fraction isolated from Algerian Linum usitatissimum L. seeds against toxigenic Aspergillus. Asian Pac J Trop Biomed 3: 443-448.

AGORAMOORTHY G，CHANDRASEKARAN M, VENKATESALU V AND HSU MJ. 2007. Antibacterial and antifungal activities of fatty acid methyl esters of the blindyour-eye mangrove from India. Braz J Microbiol 38: 739-742.

ARA N AND NUR H. 2009. In vitro antioxidant activity of methanolic leaves and flowers extracts of Lippia alba. Res J Medicine Med Sci 4: 107-110.

ARAÚJO SG, PINTO MEA, SILVA NL, SANTOS FJL, CASTRO AHF AND LIMA LARS. 2013. Antioxidant and allelopathic activities of extract and fractions from Rosmarinus officinalis. BBR - Biochem Biotechnol Rep 2: $35-43$. 
ARNAO MB, CANO A AND ACOSTA M. 2001. The hydrophilic and lipophilic contribution to total antioxidant activity. Food Chem 73: 239-244.

BOCCA AL, AMARAL AC, TEIXEIRA MM, SATO PK, SHIKANAI-YASUDA MA AND SOARES FELIPE MS. 2013. Paracoccidioidomycosis: eco-epidemiology, taxonomy and clinical and therapeutic issues. Future Microbiol 8: 1177-1191.

BRUMMER E, CASTANEDA E AND RESTREPO A. 1993. Paracoccidioidomycosis: an update. Clin Microbiol Rev 6: 89-117.

BURDA S AND OLESZEK W. 2001. Antioxidant and antiradical activities of flavonoids. J Agric Food Chem 49: 2774-2779.

CABRAL GA. 2005. Lipids as bioeffectors in the immune system. Life Sci 77: 1699-1710.

CHANDRASEKARAN M, SENTHILKUMAR A AND VENKATESALU V. 2011. Antibacterial and antifungal efficacy of fatty acid methyl esters from the leaves of Sesuvium portulacastrum L. Eur Rev Med Pharmacol Sci 15: 775-780.

CHU YF, SUN J, WU X AND LIU RH. 2002. Antioxidant and antiproliferative activities of common vegetables. J Agric Food Chem 50: 6910-6916.

CLINICAL AND LABORATORY STANDARDS INSTITUTE. 2008. Reference method for broth dilution antifungal susceptibility testing of yeasts: approved standard $-3^{\text {rd }}$ ed., CLSI document M27-A3. CLSI, Wayne, PA, USA.

COUTINHO ZF, SILVA D, LAZÉRA M, PETRI V, OLIVEIRA RM, SABROZA PC AND WANKE B. 2002. Paracoccidioidomycosis mortality in Brazil (1980-1995). Cad Saúde Pública RJ 18: 1441-1454.

CRUZ RC, WERNECK SMC, OLIVEIRA CS, SANTOS PC, SOARES BM, SANTOS DA AND CISALPINO PS. 2013. Influence of different media, incubation times, and temperatures for determining the MICs of seven antifungal agents against Paracoccidioides brasiliensis by microdilution. J Clin Microbiol 51: 436-443.

DE OLIVEIRA HC, ASSATO PA, MARCOS CM, SCORZONI L, DE PAULA E SILVA AC, DA SILVA JDEF, SINGULANI JDEL, ALARCON KM, FUSCOALMEIDA AM AND MENDES-GIANNINI MJ. 2015. Paracoccidioides-host Interaction: An Overview on Recent Advances in the Paracoccidioidomycosis. Front Microbiol 6: 1319 .

DESBOIS AP AND SMITH VJ. 2010. Antibacterial free fatty acids: activities, mechanisms of action and biotechnological potential. Appl Microbiol Biotechnol 85: 1629-1642

ERDEMOGLU N AND KUSMENOGLU S. 2003. Fatty acid composition of Zygophyllum fabago seeds. Chem Nat Compd 39: 595-596.
FERREIRA MS. 2009. Paracoccidioidomycosis. Paediatr Respir Rev. 10: 161-165.

FINNEY DJ. 1980. Probit analysis, a statical treatment of the sigmoid response curve, Cambridge: University Press, 333 p.

GOLEBIOWSKI M, CERKOWNIAK M, DAWGUL M, KAMYSZ W, BOGÚS M AND STEPNOWSKI P. 2013. The antifungal activity of the cuticular and internal fatty acid methyl esters and alcohols in Calliphora vomitoria. Parasitology 140: 972-985.

HAHN RC AND HAMDAN JS. 2000. Effects of amphotericin $\mathrm{B}$ and three azole derivatives on the lipids of yeast cells of Paracoccidioides brasiliensis. Antimicrob Agents Chemother 44: 1997-2000.

JOHANN S, CISALPINO PS, WATANABE GA, COTA BB, DE SIQUEIRA EP, PIZZOLATTI MG, ZANI CL AND DE RESENDE MA. 2010. Antifungal activity of extracts of some plants used in the Brazilian traditional medicine against the pathogenic fungus Paracoccidioides brasiliensis. Pharm Biol 48: 388-396.

LAMPRONTI I, MARTELLO D, BIANCHI N, BORGATTI M, LAMBERTINI E, PIVA R, JABBAR S, CHOUDHURI MSK, KHAN TH AND GAMBARI R. 2003. In vitro antiproliferative effects on human tumor cell lines of extracts from the Bangladeshi medicinal plant Aegle marmelos Correa. Phytomedicine 10: 300-308.

LIMA LARS, ALVES TMA, ZANI CL, PIMENTA LPS AND BOAVENTURA MAD. 2012. Antioxidant and cytotoxic potential of fatty acid methyl esters from the seeds of Annona cornifolia A. St. -Hil. (Annonaceae). Food Res Int 43: 873-875.

LIMA LARS, JOHANN S, CISALPINO PS, PIMENTA LPS AND BOAVENTURA MAD. 2011. In vitro antifungal activity of fatty acid methyl esters of the seeds of Annona cornifolia A. St. Hil. (Annonaceae) against pathogenic fungus Paracoccidioides brasiliensis. Rev Soc Bras Med Trop 44: 777-780.

LIMA LARS, PIMENTA LPS AND BOAVENTURA MAD. 2010. Acetogenins from Annona cornifolia and their antioxidant capacity. Food Chem 122: 1129-1138.

ODDS FC, BROWN AJP AND GOW NAR. 2003. Antifungal agents: mechanisms of action. Trends Microbiol 11: 272-279.

PANIAGO AM, AGUIAR JI, AGUIAR ES, CUNHA RV, PEREIRA GROL, LONDERO AT AND WANKE B. 2003. Paracoccidioidomycosis: a clinical and epidemiological study of 422 cases observed in Mato Grosso do Sul. Rev Soc Bras Med Trop 36: 455-459.

PRADO M, SILVA MB, LAURENTI R, TRAVASSOS LR AND TABORDA CP. 2009. Mortality due to systemic mycoses as a primary cause of death or in association with AIDS in Brazil: a review from 1996 to 2006. Mem Inst Oswaldo Cruz 104: 513-521.

PYUN MS AND SHIN S. 2006. Antifungal effects of the volatile oils from Allium plants against Trichophyton 
species and synergism of the oil with ketoconazole. Phytomedicine 13: 394-400.

RUFINO MSM, ALVES RE, FERNANDES FAN AND BRITO E. 2011. Free radical scavenging behavior of ten exotic tropical fruits extracts. Food Res Int 44: 2072-2075.

SHIKANAI-YASUDA MA. 2015. Paracoccidioidomycosis treatment. Rev Inst Med Trop Sao Paulo 57: 31-37.

TRAVASSOS LR AND TABORDA CP. 2012. New advances in the development of a vaccine against paracoccidioidomycosis. Front Microbiol 3: 212.
TRAVASSOS LR, TABORDA CP AND COLOMBO AL. 2008. Treatment options for paracoccidioidomycosis and new strategies investigated. Expert Rev Anti-Infect Ther 6: $251-262$.

YAMAMOTO Y, HAGA S, NIKI E AND KAMIYA Y. 1984. Oxidation of lipids. V. Oxidation of Methyl Linoleate in aqueous dispersion. Bull Chem Sot Jpn 57: 1260-1264.

WHITE RL, BURGESS DS, MANDURURU M AND BOSSO JA. 1996. Comparison of three different in vitro methods of detecting synergy: time kill, checkboard, and E-test. Antimicrob Agents Chemother 40: 1914-1918. 